\title{
Kausalitas Anak dan Orang Tua : Relevansi antara Teori Konvergensi dalam Psikologi Pendidikan Barat dengan Teori Fitrah dalam Perspektif Islam
}

\author{
Sukarman 1 \\ ${ }^{1}$ Universitas Islam Nahdlatul Ulama Jepara \\ pakar@unisnu.ac.id
}

\begin{abstract}
This article is a conceptual research study that would explain the pattern of causality relationships between children and parents according to the theory of convergence in western education and the view of fitrah theory in the perspective of Islamic education. In this research, these two theories are compared,and they were found relevance to each other. The interesting thing in this study is the theory that places children as those who receive education while parents positioned as parties that contribute to children's education in children's lives. In the Islamic view, compilation of parents must complete education (education) for children will focus on the lives of their parents later. Related in this case there would be a causal relationship between there. This study is based on the lack of understanding of educational responsibilities between teachers and parents. The research method uses literature review in qualitative descriptive studies. This research tries to compare between western education theory and Islamic education theory. The conclusion from the study of convergence theory and fitrah theory is a meeting point between the two theories sourced from different sources with western literature and Islamic literature.
\end{abstract}

Keywords: causality, convergence, Islam

\begin{abstract}
Abstrak: Artikel ini merupakan kajian penelitian konseptual yang akan memaparkan pola hubungan kausalitas anak dan orang tua menurut teori konvergensi dalam psikologi pendidikan barat dan pandangan teori fitrah dalam perspektif pendidikan Islam. Jika kedua teori ini disandingkan maka akan ditemukan relevansi satu sama lain. Hal yang menarik dalam kajian ini adalah kedua teori ini menempatkan seorang anak sebagai pihak penerima pengaruh (pendidikan) sedangkan orang tua diposisikan sebagai pihak pemberi pengaruh (pendidikan) dalam kehidupan anak. Dalam pandangan Islam ketika orang tua telah tiada maka hasil pemberian pengaruh (pendidikan) terhadap anak akan berpengaruh pada kehidupan orang tuanya kelak. Sehingga dalam hal ini akan terdapat hubungan kausalitas antara keduanya. Kajian ini dilatarbelakangi adanya persoalan ketidaksepemahaman tentang tanggung jawab pendidikan antara guru dan orang tua. Metode penelitian menggunakan literature review dalam kajian deskriptif kualitatif. Penelitian ini mencoba membandingkan antara dua teori pendidikan barat dan teori pendidikan Islam. Simpulan dari kajian tentang teori konvergensi dan teori fitrah adalah adanya satu titik temu antara keduanya meskipun kedua teori tersebut bersumber dari sumber yang berbeda yakni literatur barat dan literatur Islam.
\end{abstract}

Kata kunci: kausalitas, konvergensi, Islam. 


\section{WACANA}

\section{Pendahuluan}

Keberhasilan dan kegagalan dalam dunia pendidikan sering kali menjadi persoalan yang masih saja diperdebatkan. Dalam hal ini adalah persoalan yang melibatkan antara orang tua dan guru. Pihak yang acap kali rentan dengan hal tersebut adalah orangtua dan guru. Tidak menjadi persoalan ketika hal yang nampak ke permukaan adalah keberhasilan dalam pendidikan bagi anak. Hal-hal positif dalam dunia pendidikan umumnya tidak terlalu banyak mengundang persoalan. Namun berbeda cerita ketika hal yang dijumpai adalah kegagalan ataupun hal negatif dalam pendidikan. Orang tua sering kali menyudutkan lembaga pendidikan tempat putra dan putrinya belajar, dalam hal ini secara khusus adalah teruntuk guru. Tidak sedikit orang tua yang mengalamatkan kekesalan, kekecewaan bahkan kemarahannya terhadap guru. Para orang tua berasumsi bahwa gurulah yang memiliki tanggung jawab penuh dalam mendidik anaknya. Sehingga guru berkewajiban membuat anak menjadi pandai. Guru dianggap sebagai unsur pendidikan utama penentu keberhasilan. Sehingga ketika ada ada kegagalan atau ketidakpuasan orang tua terhadap prestasi belajar anak bagi orangtua pihak yang paling bertanggung jawab adalah guru. Hal ini tidak sepenuhnya salah karena pada hakikatnya guru sebagai pendidik memiliki tugas dan kewajiban mengarahkan potensi anak/peserta didiknya (Sukardjo \& Qomarudin, 2012: 96).

Di sisi lain guru berasumsi bahwa orang tua memiliki peran dan fungsi yang sentral bagi anak. Keluarga juga memiliki tanggung jawab terhadap pendidikan anak. Tugas dan tangung jawab mendidik bukan semata-mata dari guru. Orangtua dalam hal ini keluarga merupakan lembaga pendidikan yang pertama dan utama bagi anak (Abu Ahmadi \& Uhbiyati, 2015: 172). Keluarga dan orangtua memiliki hak otonom dalam mendidik anak tanpa harus terikat dengan regulasi. Dalam banyak aspek keluarga memiliki otoritas dalam menentukan tujuan pendidikan, materi pembelajaran yang akan diberikan, strategi yang digunakan, metode dan media pembelajaran juga tidak terikat pula dengan evaluasi.dan besaran nominal biaya endidikan yang harus dibayarkan. Pendidikan dalam keluarga juga tidak terikat berapa lama masa studi. Masa pembelajaran dalam keluarga tidak dibatasi dengan durasi jam, menit, dan detik. Pendidikan dalam keluarga berlangsung sepanjang waktu, setiap hari setiap bulan dan sepanjang tahun. Pada hakikatnya pendidikan itu berlangsung sepanjang hayat (life long education). Pendidikan sepanjang hayat 


\section{WACANA}

menjadi salah satu asas pendidikan. Sebagaimana dinyatakan dalam ketetapan MPR No. IV/1978 yang menyatakan bahwa: pendidikan berlangsung seumur hidup dan dilaksanakan dalam lingkungan rumah tangga, sekolah, dan masyaakat.("TAP MPR No.IV 1978 - Google Scholar," n.d.). dalam pandangan Islam pendidikan sepanjang hayat merupakan kewajiban bagi setiap muslim baik laki-laki maupun perempuan, selagi masih bernafas artinya ketika lahir sampai dengan meninggal dunia (Wahyuddin, 2017).

Sejatinya keluarga memiliki banyak fungsi bagi anak (Napis, 2017: 97-98). Peran tersebut antara lain: pertama, fungsi biologis artinya keluarga memiliki fungsi yang terkait dengan pemenuhan segala kebutuhan biologia misalnya sandang (pakaian), pangan (makanan) dan papan (tempat tinggal). Kedua, fungsi ekonomi artinya keluarga memiliki fungsi untuk mememnuhi kebutuhan ekonomi anakanaknya baik kebutuhan lahiriyah maupun batiniyah. Ketiga, fungsi edukatif (pendidikan) dalam hal ini keluarga memiliki fungsi membimbing mengarahkan dan menanamkan nilai-nilai agama, sosial, etika dan lain sebagainya. Keempat, fungsi pencerahan yakni keluarga memiliki organisasi terkecil dalam kehidupan berbangsa dan bernegara, keluarga memiliki fungsi untuk menciptakan suatu kondisi dimana anak-anak dikondisikan untuk dapat beradaptasi dengan segala aspek misalnya budaya dan agama sebagai bagian yang tidak bisa lepas dari kehidupan berbangsa dan bernegara. Kelima, fungsi agama artinya keluarga memiliki kewajiban mengarahkan anak sebagai mahluk beragama karena pada dasarnya manusia adalah mahluk beragama (homo religius).

Lebih lanjut menurut UU No.2 tahun 1989 bab IV 10 ayat 4 menyatakan bahwa pendidikan keluarga adalah pendidikan luar sekolah yang yang diselenggarakan dalam keluarga dan yang memberikan keyakinan agama, nilai moral dan keterampilan (Undang-Undang, 1989). Sedangkan dalam undang-undang No.20 Tahun 2003 pendidikan dalam lengkungan rumah tangga / keluarga adalah pendidikan pada jalur informal (Undang-undang RI No.20 tahun 2003 tentang sistem pendidikan Nasional, n.d.).

Dari kedua persoalan terkait tanggung jawab pendidikan tersebut terlepas apakah pendapat orang tua ataukah pendapat guru. Perlu kiranya kita mengulas lebih lanjut persoalan tersebut dari dua sudut pandang yakni teori konvergensi yang dipopulerkan oleh seorang tokoh psikologi pendidikan Jerman William stern dan 


\section{WACANA}

teori pendidikan fitrah yang diusung dari ajaran Islam yang bersumber dari alQur'an dan Hadis.

Hal yang tidak kalah penting untuk dipahami bersama adalah adalah faktor yang mempengaruhi belajar. Secara umum dibedakan menjadi dua yakni faktor individual atau faktor internal dan faktor dari luar individu atau faktor eksternal. Secara lebih rinci dapat diuraikan sebagai berikut (Purwanto, 2013)..

Pertama, Kematangan/pertumbuhan, kematangan dalam hail ini diartikan sebagai potensi kemampuan berpikir, menalar dan menggunakan daya rasio. Sedangkan pertumbuhan diartikan sebagai peningkatan secara lahiriyah/jasmaniah. Misalnya pendek menjadi tinggi, kecil menjadi besar dan seterusnya. tingkat kematangan/pertumbuhan memberi pengaruh terhadap keberhasilan belajar. Anak yang memiliki kematangan/pertumbuhan yang baik akan berdampak baik pula hasil belajarnya. Sebaliknya anak dengan kematangan/pertumbuhan yang buruk akan juga berdampak buruk bagi prpses dan hasil belajarnya.(Purwanto, 2013)

Kedua, kecerdasan/intelegensi, kecerdasan diyakini sebagai hal mendasar yang dijadikan faktor yang penting dalam belajar. Artinya kecerdasan sangat dibutuhkan dalam belajar. Seberapa besar atau seberapa tinggi kecerdasan setiap individu akan mempengaruhi proses dan hasil belajar setiap individu. Syekh azzarnuji dalam kitab Ta'lim al-Muta'allim menyatakan bahwasanya sayyidina Ali ra berpesan untuk mendapatkan ilmu perlu memiliki enam syarat sebagai bekal menuntut ilmu. Yakni kecerdasan, kesungguhan, sabar, bekal/biaya, petunjuk guru dan perlu waktu yang lama (Az-Zarnuji, 1978).

Ketiga, latihan dan ulangan, latihan dan ulangan juga mempengaruhi belajar. Mengapa demikian. Pepatah mengatakan "practice makes perfect" artinya sering berlatih dan mengulang-ulang pelajaran akan membuat setiap individu lebih mudah menguasai pelajaran tertentu. Orang yang yang menghafal al-Qur'an umumnya dilakukan dengan mengulang-ulang bacaan sehingga meningkat menjadi hafal. Orang yang sering bermain bola maka kelihaiannya memainkan bola akan terasah dengan banyaknya latihan dan pengulangan.

Keempat, motivasi. Dorongan berpengaruh besar dalam belajar, belajar tergantung juga dengan motivasi yang dimiliki oleh individu. Kesungguhan dan keengganan juga menentukan keberhasilan belajar. Syekh Az-Zarnuji dalam ta'lim al-Mutallim menyatakan "man jadda wajada" ungkapan ini mengandung maksud 


\section{WACANA}

siapa yang sunguh-sungguh maka ia akan memperoleh apa yang dicita-citakan. Termasuk dalam mencapai tujuan pendidikan. Tujuan penddikan menurut UNESCO yang dinyataan ke dalam empat pilar pendidikan yakni learning to know, learning to do, learning to be, learning lo live together (Akademik, 2008). Hamdu dalam penelitiannya tentang pengaruh motivasi belajar siswa terhadap prestasi belajar IPA di Sekolah Dasar menyatakan bahwa motivasi secar signifikan memberi pengaruh pada prestasi belajar (Hamdu \& Agustina, 2011) senada dengan hal itu Kiswoyowati menyatakan bahwa motivasi memberikan pengaruh pada kegiatan belajar siswa, motivasi terhadap kecakapan hidup siswa, dan kegiatan belajar siswa terhadap kecakapan hidup siswa (Kiswoyowati, 2011)

Kelima, sifat-sifat pribadi seseorang, sifat individu dalam belajar juga menentukan keberhasilan individu dalam belajar. Misalnya sifat malas pada umumnya membawa dampak negative dalam hasil belajar. Demikian sebaliknya sifat rajin umumnya membawa dampak positif pada keberhasilan belajar.

Keenam, keadaan keluarga. Tidak dapat dipungkiri bahwa keluarga memang menjadi salah satu faktor penentu keberhasilan belajar sebagaimana telah banyak disinggung. Keluarga diyakini sebagai lembaga pendidikan yang pertama dan utama bagi pendidikan anak.

Ketujuh, guru dan cara mengajar. Aspek ketujuh inilah yang sebenarnya bagi sebagian masyarakat menjadi perhatian dan tidak jarang menjadi sorotan masyarakat. Masyarakat acap kali mengalamatkan tugas dan tanggung jawab pendidikan kepada guru. Seolah-oplah guru sajalah yang menjadi penentu kegagalan dan keberhasilan bagi pendidikan anak. Meskipun memang sudah menjadi trade mark bahwa guru tugasnya adalah mendidik. Guru juga menjadi penentu keberhasilan dan kegagalan peserta didik. Baik dan buruknya guru mempengaruhi ppembelajaran. Setidaknya dapat diketahui dari kompetensinya. Kompetensi professional, kompetensi pedagogic, kompetensi personal , dan kompetensi sosial sebagaimana diamanatkan dalam PP No. 19 Tahun 2005 pasal 28 ayat (3). Bahwa kompetensi sebagai agen pembelajran pada jenjan pendidikan dasar dan menegah serta pendidikan dasar dan menengah serta pendidikan anak usia dini (Saragih, 2008).

Kedelapan, alat-alat pelajaran. Alat-alat pelajaran sebagai aspek yang juga tidak bisa dipandang sebelah mata dan diabaikan begitu saja. Alat-alat disini tidak 


\section{WACANA}

hanya dimaknai dengan media pembelajaran yang bersifat material saja berupa sarana dan prasarana namun juga alat yang bersifat immaterial misalnya kewibawaan, ganjaran (reward) dan hukuman (punishment). Alat pelajaran dan sarana yang memadai dapat mengatasi kesulitan belajar (Ristiyani \& Bahriah, 2016). Dalam penelitian Lia tentang penggunaan alat peraga KIT IPA terhadap hasil belajar siswa memperoleh simpulan bahwa terdapat adanya pengaruh yang signifikan penggunaan alat peraga terhadap hasil belajar (Lia, 2012).

Kesembilan, motivasi sosial. Motivasi sosial juga menjadi salah satu penentu keberhasilan belajar. Belajar identik dengan kegiatan memberian pengaruh dari guru/pendidik kepada peserta didik. Dalam halini ada interaksi. Dalam interaksi membutuhkan motivasi sosial.

Kesepuluh, lingkungan dan kesempatan. Demikian halnya dengan lingkungan sebagaimana telah disinggung bahwa lingkungan menjadi salah satu aspek penentu dalam pendidikan atau pembelajaran. Terlepas apakah itu lingkungan keluarga, lingkungan sekolah ataupun lingkungan masyarakat yang dikenal dengan tri pusat pendidikan (Abu Ahmadi \& Uhbiyati, 2015). Senada dengan Abu Ahmadi dan Nur Uhbiyati yang mengusung konsep tri pusat pendidikan Ki Hajar Dewantara, Abdurrahman An-Nahlawi juga telah memaparkan konsep tersebut jauh sebelum Ki Hajar Dewantara (An-Nahlawi, 1403).

\section{Metode}

Kajian tentang hubungan kausalitas antara orangtua dan anak ini adalah kajian yang menggunakan metode penelitian deskriptif kualitatif. Yang mengkaji sebuah problem yang menyajikan data-data deskriptif yang ditemui di lapangan. Kemudian persoalan /masalah yang ditemuai coba dikaji melalui kajian pusaka. Sehingga kajian ini menggali dari sumber atau literatur kepustakaan (library research). Tulisan ini mengkaji beberapa literature sebanyak 23 literatur meliputi buku, jurnal ilmiah, kitab yang terkait erat dengan ilmu pendidikan, ilmu pendidikan Islam, teori fitrah dan psikologi pendidikan. Teknis analisis data yang digunakan dalam kajian ini adalah komparasi atau perbandingan dari dua konsep pemikiran dari dua sumber yang berbeda. Pertama, konsep pendidikan barat yang memaparkan teori konvergensi yang diusung oleh tokoh psikologi pendidikan Jerman William Stern. Kedua, kajian ini akan mengulas relevansi antara teori 


\section{WACANA}

konvergensi terhadap teori fitrah. Kemudian mencari titik temu / relevansi kedunya sampai menemukan kesimpulan tentang hubungan kausalitas antara orang tua dan anak dalam perspektif kedua teori tersebut.

\section{Hasil}

Dalam pengkajian pustaka tentang hubungan kausalitas orang tua dan anak ini penulis akan memaparkan letak hubungan kausaliatas antara keduanya dari sudut pandang teori konvengensi dan teori fitrah, kemudian mengkaji untuk menemukan relevansi, persamaan dan perbedaan satu sama lain.

\section{Pandangan teori konvergensi}

Teori konvergensi pada dasarnya adalah sebuah teori yang merupakan kombinasi antara dua teori sebelumnya yakni teori nativisme yang diusung oleh Arthur Schopenhour (1788-1860) dan teori empirisme yang diusung oleh John locke (1632-1704).

Teori nativisme berpendapat bahwa perkembangan individu itu ditentukan oleh pembawaan.(Syah, 2014) Teori nativisme sendiri mengandung arti bawaan berasal dari kata native atau nativus. Teori ini berpendapat bahwa hal yang dominan dalam pendidikan anak adalah faktor bawaan atau hereditas. Dalam hal ini setiap anak membawa potensi yang diperoleh secara genetis dari pendahulunya termasuk ayah dan ibunya. Potensi bawaan yang bersifat genetis tersebut dapat berupa aspek fisiologis atau kenampakan lahiriah misalnya, postur tubuh, bentuk rambut, wajah, warna kulit dan lain sebagainya. Ketika ayah atau ibu memiliki karakteristik fisik berbadan tinggi maka tidak menutup kemungkinan hal tersebut akan diturunkan kepada anaknya, jika orang tua berkulit putih ataupun gelap hal tersebut juga akan diturunkan kepada anaknya. Demikian halnya dengan potensi psikologis, teori nativisme berpandangan bahwa aspek-aspek psikologis misalnya sifat, kecerdasan juga dimungkinkan akan menurun dari orang tua kepada anaknya. Orang tua dengan kecerdasan yang baik akan menurun kepada anak turunnya. Sifat yang dimiliki oleh orang tua juga akan menurun kepada anak keturunnannya. Misalnya pendiam, cerewet, sensitif dan seterusnya (Suryabrata, 2014). 


\section{WACANA}

Dari paparan tersebut diatas dapat diambil simpulan bahwa orang tua memiliki pengaruh besar yang berpengaruh pada pertumbuhan dan perkembangan seorang individu. Potensi orang tua menurut teori nativisme memiliki dampak dan pengaruh besar bagi perkembangan anak. Dengan demikian terdapat hubungan sebab akibat atau kausalitas antara orang tua terhadap anak.

Dalam menyikapi persoalan yang dipaparkan dalam latar belakang tentunya dapat diambil pelajaran bahwa keberhasilan dalam pendidikan sangat tidak etis jika orang tua hanya menuntut dan menyudutkan guru ketika menjumpai kegagalan atau ketidak puasan dalam hasil pendidikan. Orang tua harusnya menyadari bahwa dirinya menempati kedudukan yang dominan dalam mempengaruhi perkembangan anak. Teori nativisme mengingatkan orang tua untuk melakukan introspeksi diri ketika menjumpai kegagalan atau ketidak puasan dari hasil pembelajaran anak. Sehingga orang tua tidak mudah untuk menyalahkan atau menyudutkan guru. Orang tua juga perlu menyadari bahwa faktor penentu keberhasilan pendidikan seorang anak bukan semata-mata terletak pada guru saja.

Teori empirisme memandang bahwa seorang anak/individu diumpamakan seperti kertas putih (tabularasa) sehingga teori ini juga dikenal dengan teori tabularasa. Teori ini memandang bahwa perkembangan individu / anak didominasi oleh faktor lingkungan. Lingkungan dalam hal ini adalah segala hal yang bersifat eksternal / diluar diri pribadi anak / individu. (Syah, 2014)

Tokoh pendidikan nasional Indonesia dalam konsep Tri Pusat Pendidikan menyatakan bahwa setidaknya terdapat tiga pusat / lingkungan pendidikan. Pertama, lingkungan keluarga. Kedua, lingkungan sekolah. Ketiga, lingkungan masyarakat (Abu Ahmadi \& Uhbiyati, 2015).

\section{Pandangan teori fitrah}

Pada dasarnya manusia terlahir telah membawa fitrahnya masingmasing. Terlepas ia terlahir dari rahim siapa, pejabat atau penjahat, penguasa ataupun rakyat jelata, terlahir dalam pernikahan maupun di luar ikatan pernikahan semua anak yang terlahir adalah diciptakan dengan fitrah. meskipun tema fitrah memiliki banyak pengertian. 


\section{WACANA}

Kata fitrah sebenarnya berasal dari kata bahasa Arab "fatara" yang memiliki arti membelah atau membuka. Apabila kata tersebut dihubungkan denagn puasa ramadlon maka memiliki arti berbuka puasa. Kemudian jika kata fitrah diartikan kembali pada fitrah maka dapat ditafsirkan kembali pada penciptaan awal manusia atau keadaan asal atau keadaan asli (Raharjo, 1996). Fitrah juga memiliki arti bersih dari segala noda dan dosa dari aspek akal dan juga nafsunya, sehingga dapat dipahami bahwa setiap anak yang terlahior adalah dalam keadaan suci bersih (Basri \& Saebani, 2010). Hal ini memiliki relevansi dengan pandangan teori empirisme tabularasa John Locke yang menyatakan bahwa setiap anak yang terlahir dalm kondisi suci bersih. Anak diumpamakan seperti kertas putih tanpa noda sehingga dapat ditulis, digambar ataupun diwarnai sesuka hati sesuai denagn kehendak pendidik, orang tua maupun lingkungan.

Teori fitrah sebenarnya merupakan teori yang bersumber dari literatur pendidikan Islam. Salah satu yang memiliki relevansi dengan teori konvergensi adalah merujuk pada hadis Rasulullah saw.

$$
\text { كل مولود يولد على الفطرة فابو اه يهودانه او ينصر انه او يمجسانه ( رواه البيهقى) }
$$

"Setiap anak yang dilahirkan telah membawa fitrah, maka kedua orang tuanyalah yang menyebabkan anak tersebut menjadi yahudi, nasrani, atau majusi. (HR. Baihaqi).

Meskipun pada Hadis tersebut menyebutkan bahwa setiap anak yang terlahir itu dalam keadaan suci putih bersih dari noda namun pada perkembangannya ada pengaruh dari kedua orang tuanya. Dalam keterangan hadis tersebut di atas juga menegaskan kedua orang tuanyalah yang menyebabkan seorang anak bisa menjadi Yahudi, Nasrani atau majusi. Hal ini terkait dengan fitrah dasar manusia sebagai mahluk bertuhan.

Lebih lanjut Abuddin Nata menyatakan bahwa meskipun anak terlahir dalam keadan fitrah (suci) namaun orang tua memberi corak pada pendidikan anak (Nata, 2012). Pernyataan tersebut merujuk pada salah satu firman Allah dalam al-Qur'an.

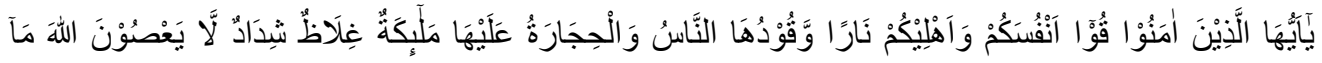

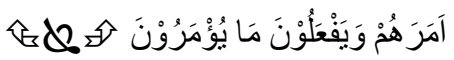




\section{WACANA}

"Hai orang-orang yang beriman, peliharalah dirimu dan keluargamu dari api neraka yang bahan bakarnya adalah manusia dan batu; penjaganya malaikatmalaikat yang kasar, keras, dan tidak mendurhakai Allah terhadap apa yang diperintahkan-Nya kepada mereka dan selalu mengerjakan apa yang diperintahkan". (Q.S. At-Tahrim: 6)

Ayat tersebut mengindikasikan bahwa setiap individu diperintahkan untuk menjaga diri dan keluarga dari api neraka. Termasuk orang tua menjaga fitrah anak / keselamatan anak dari siksa api neraka. Mencegah diri dan keluarga dari api neraka tentunya dengan memberikan pendidikan tentang agama. dalam alQur'an .Surat Ar-Rum: 30 menyatakan bahwa fitrah dasar yang harus dijaga adalah fitrah agama.

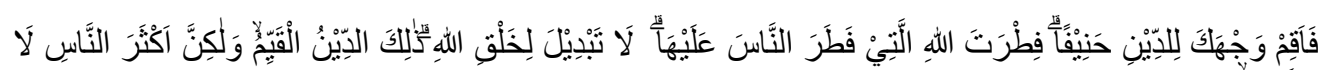

"Maka hadapkanlah wajahmu dengan lurus kepada agama Allah; (tetaplah atas) fitrah Allah yang Telah menciptakan manusia menurut fitrah itu. tidak ada peubahan pada fitrah Allah. (Itulah) agama yang lurus; tetapi kebanyakan manusia tidak mengetahui. (Q.S. Ar-Rum : 30)

Dalam rangka menjaga fitrah dasar anak yakni fitrah agama, al-Qur'an memberikan ibroh sebagaimana Luqman al-Hakim terhadap anaknya. Luqman al-Hakim memberikan banyak kepada anaknya, yakni:

Pertama, menjauhkan anak dari perbuatan menyekutukan Allah.

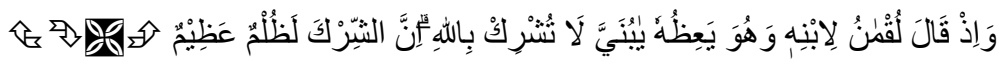

"Dan (Iingatlah) ketika Luqman Berkata kepada anaknya, di waktu ia memberi pelajaran kepadanya: "Hai anakku, janganlah kamu mempersekutukan Allah, Sesungguhnya mempersekutukan (Allah) adalah benar-benar kezaliman yang besar". (Q.S. Luqman: 13)

Kedua, membentuk menjadi anak yang berbakti pada ibu bapaknya.

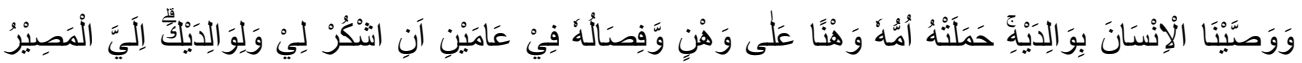

$$
\begin{aligned}
& \text { 合包8 }
\end{aligned}
$$

“Dan kami perintahkan kepada manusia (berbuat baik) kepada dua orang ibubapanya; ibunya telah mengandungnya dalam keadaan lemah yang bertambahtambah, dan menyapihnya dalam dua tahun, bersyukurlah kepadaku dan kepada dua orang ibu bapakmu, Hanya kepada-Kulah kembalimu." (Q.S. Luqman: 14) Ketiga, membentuk anak untuk menjadi pribadi kepada Allah swt. 


\section{WACANA}

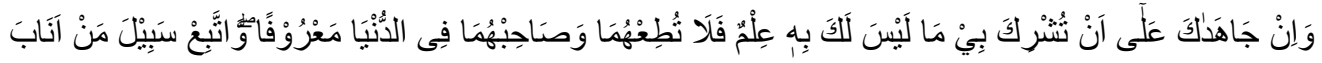

$$
\begin{aligned}
& \text { 䍒 }
\end{aligned}
$$

“Dan jika keduanya memaksamu untuk mempersekutukan dengan Aku sesuatu yang tidak ada pengetahuanmu tentang itu, Maka janganlah kamu mengikuti keduanya, dan pergaulilah keduanya di dunia dengan baik, dan ikutilah jalan orang yang kembali kepada-Ku, Kemudian Hanya kepada-Kulah kembalimu, Maka Kuberitakan kepadamu apa yang Telah kamu kerjakan." (Q.S. Luqman: 15) Keempat, menjadikan anak yang berhati-hati terhadap perbuatannya.

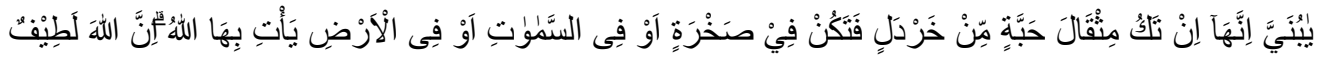

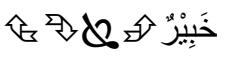
(Luqman berkata): "Hai anakku, Sesungguhnya jika ada (sesuatu perbuatan) seberat biji sawi, dan berada dalam batu atau di langit atau di dalam bumi, niscaya Allah akan mendatangkannya (membalasinya). Sesungguhnya Allah Maha Halus lagi Maha Mengetahui. (Q.S. Luqman: 16)

Kelima, membentuk menjadi anak yang selalu taat untuk mendirikan sholat.

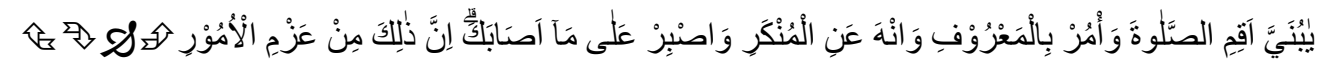
“ Hai anakku, Dirikanlah shalat dan suruhlah (manusia) mengerjakan yang baik dan cegahlah (mereka) dari perbuatan yang mungkar dan bersabarlah terhadap apa yang menimpa kamu. Sesungguhnya yang demikian itu termasuk hal-hal yang diwajibkan (oleh Allah).” (Q.S. Luqman: 17)

Demikian besarnya dorongan Islam terutama bagi orang tua dalam memberikan pengaruh terhadap anak. Sehingga dapat diambil kesimpulan bahwa dalam pandangan Islam orangtua memiliki hubungan sebab akibat terhadap anak. Sehingga bisa dikatakan bahwa sukses tidaknya perkembangan ataupun pendidikan seorang anak merupakan rangkaian sebab akibat dari pengaruh orang tua, bahkan selamat atau tidak selamatnya anak baik dalm kehidupan dunia dan akhirat adalah merupakan satu rangkaian kausalitas orang tua terhadap anak. Dengan demikian dalam pandangan Islam kausalitas orang tua terhadap anak ini bisa dikatakan kausalitas mutlak.

Tidak berhenti sampai di situ saja, hubungan kausalitas antara orang tua dengan anak ini tidak hanaya terjadi satu arah saja namun terjadi dua arah. Dalam arti orang tua dapat menjadi pengaruh terhadap orang tua dan sebaliknya anakpun dapat mempengaruhi terhadap orang tua. 
WACANA

عن ابى هريرة رضي الله عنه ان رسول الله صلى الله عليه وسلم قال:إذا مات ابن ادم انقطع عمله إلا من ثلاث :

صدقة جارية او علم ينتفع به اوولا صالح يدعوله له (رو اه مسلم)

Dari Abu Hurairah RA, sesungguhnya Rasulullah saw bersabda: Ketikaanak Adam meninggal dunia maka terputuslah amalnya kecuali tiga perkara: shodaqoh jariyah, ilmu yang bermanfaat dan anak soleh yang mau mendoakannya. (HR. Muslim).

Hadis yang diriwayatkan oleh Abu Hurairah ra di atas menyatakan adanya hubungan kausalitas yang berlangsung secara dua arah. Yakni hubungan kausalitas orang tua terhadap anak dan sebaliknya hubungan kausalitas anak terhadap orang tua. Dari kutipan hadis tersebut menyatakan bahwa orang yang telah meniggal dunia akan terputus segala amalnya, kecuali tiga perkara. Artinya tiga perkara tersebut tetap akan memberi manfaat kepada orang yang telah meningga tersebut. Pertama, sedekah jariyah. Sedekah disifati jariyah artinya sedekah yang pahalanya selalu mengalir tanpa terputus meskipun seorang tersebut telah meninggal dunia. Misalnya sedekah yang diberikan untuk kemaslahatan umum yang tetap memberi manfaat bagi banyak orang dan dalam waktu yang lama. Misalnya untuk masjid, madrasah atau lainnya yang serupa. Ketika sedekah tersebut masih memberi kemaslahatan pada banyak orang maka pahalanya akan senantiasa mengalir kepada si pemberi sedekah. Kedua, ilmu yang bermanfaat. Ilmu yang bermanfaat di sini diartikan ilmu yang memberi kontribusi bagi kemaslahatan bersama. Ketika ilmu tersebut ditularkan kepada orang lain maka pahala dari ilu tersebut tetap mengalir kepada pemberi ilmu tersebut.

\section{Relevansi teori konvergensi dan teori fitrah.}

Pertama, meniadakan unsur eksternal (lingkungan) sebagai faktor yang mempengaruhi perkembangan individu, keduanya menyatakan bahwa perkembangan anak didominasi oleh unsur bawaaan yang dibawanya sejak lahir.

Kedua, dalam teori fitrah maupun teori konverensi, orang tua memiliki pengaruh dalam pendidikan anak.

Ketiga, teori fitrah dan konvergensi memposisikan anak sebagai indidvidu yang terlahir dalam kondisi suci putih bersih tida noda Sentara dalam teori konvergensi diumpamakan tabularasa atau kertas putih. Artinya kedua teori 


\section{WACANA}

tersebut menempatkan faktor eksternal termasuk lingkungan pendidikan sebagai pengaruh dalam perkembangan anak.

Keempat, teori fitrah maupun teori konverensi menyatakan adanya hubungan sebab akibat/kausalitas antara orang tua dan anak.

\section{Perbedaan teori nativisme dan teori fitrah.}

Pertama, teori fitrah menempatkan tauhid (ketuhanan) sebagai potensi asli atau potensi dasar yang dimiliki oleh individu. Sehingga agama menjadi hal dasar bagi manusia sedangkan teori konvergensi tidak menempatkan unsur tauhid di dalamnya.

Kedua, tentang hubungan kausalitas. Hubungan kausalitas dalam teori konvergensi berupa pemberian pengaruh yang didominasi oleh orang tua terhadap anak. Namun hubungan kausalitas dalam teori fitrah tidak hanya didominasi oleh orang tua terhadap anak namun juga anak terhadap orang tua.

Ketiga, orientasi. dari perbedaan pertama dan kedua dapat pula diambil kesimpulan bahwa teori konvergensi dan teori fitrah memiliki orientasi yang berbeda. Teori konvergensi cenderung antroposentris berorientasi pada kehidupan dunia semata. Sedangkan teori fitrah memiliki orientasi ganda yakni dunia dan akhirat.

\section{Diskusi}

Penelitian sebelumnya oleh Siti Fauziyah meyatakan bahwa fitrah secara harfiah diartikan sebagai ciptaan awal yang berupa potensi dasar yang dibawa oleh manusia sejak lahir baik secara jasmaniah postur badan, benuk wajah, rambut, warna kulit dan sebagainya maupun rohaniah berupa kecerdasan seni, emosi, karakter dan sebagainya. Sedangkan fitrah secara istilah diartikan sebagai potensi agama (Fauziyah, 2017).

Teori Siti Fauziyah tersebut di atas menguatkan kajian ini. Bahwa pada dasarnya ada hubungan sebab akibat antara orang tua dan anak. Fauziyah juga menyinggung soal relevansi baik persamaan maupun perbeadan dari teori fitrah dan nativisme, empirisme serta konvergensi namun tidak mengangkat adanya hubungan kausalitas antara pihak-pihak baik individu atau non individu yang terlibat dalam kajian tentang teori-teori tersebut. 


\section{WACANA}

Penelitian menurut Syamsul Bakhri tentang teori fitrah dalam islam dan relevansinya dengan teori konvergensi dalam pendidikan menyatakan adanya relevansi antara keduanya. Namun lebih banyak menyorot mengkritisi teori konvergensi dari sudut pandang Islam (Bakhri, 2016). Penelitian ini juga tidak menyinggung adanya hubungan kausaliatas yang tercermin dari dari keduanya.

\section{Simpulan}

Dalam pandangan teori konvergensi terdapat hubungan sebab akibat antara orang tua dan anak. Hal ini nampak dari dua unsur pembangunnya yakni teori nativisme dan teori empirisme. Teori nativisme memberi indikasi bahwa orang tua mewariskan faktor fisiologis maupun psikologis yang berpengaruh pada perkembangan dan pendidikan individu/anak. Teori konvergensi menyatakan bahwa faktor yang mempengaruhi perkembangan individu tidak hanya faktor internal sebagaimana dalam nativisme Arthur namun juga faktor eksternal sebagaimana empirisme John Locke. Hubungan kausalitas orang tua dan anak juga tercermin dalam pandangan teori fitrah yang juga menyatakan bahwa pada daasrnya perkembangan individu tidak semata-mata ditentukan oleh faktor internal saja karena ketika lahir semua manusia terlahir dengan membawa fitrahnya masingmasing, namaun ayah ibunya juga memberi pengaruh besar pada perkembangan anak sebagaimana dipaparkan hadis Rasulullah saw.

Relevansi teori konvergensi dengan teori fitrah memiliki kesamaan dari unsur nativisme yakni: Pertama, meniadakan unsur eksternal (lingkungan) sebagai faktor yang mempengaruhi perkembangan individu, keduanya menyatakan bahwa perkembangan anak didominasi oleh unsur bawaaan yang dibawanya sejak lahir. Kedua, dalam teori fitrah maupun teori konverensi, orang tua memiliki pengaruh dalam pendidikan anak. Ketiga, teori fitrah dan konvergensi memposisikan anak sebagai indidvidu yang terlahir dalam kondisi suci putih bersih tiada noda Sentara dalam teori konvergensi diumpamakan tabularasa atau kertas putih. Artinya kedua teori tersebut menempatkan faktor eksternal termasuk lingkungan pendidikan sebagai pengaruh dalam perkembangan anak. Keempat, teori fitrah maupun teori konverensi menyatakan adanya hubungan sebab akibat/kausalitas antara orang tua dan anak. 


\section{WACANA}

Perbedaan teori konvergensi dan teori fitrah terletak pada fitrah dasar yang dibawa oleh individu. Pertama, teori fitrah menempatkan tauhid (ketuhanan) sebagai potensi asli atau potensi dasar yang dimiliki oleh individu sehingga agama menjadi hal dasar bagi manusia. Sedangkan teori konvergensi tidak menempatkan unsur tauhid di dalamnya. Kedua, tentang hubungan kausalitas. Hubungan kausalitas dalam teori konvergensi berupa pemberian pengaruh yang didominasi oleh orang tua terhadap anak. Namun hubungan kausalitas dalam teori fitrah tidak hanya didominasi oleh orang tua terhadap anak namun juga anak terhadap orang tua. Ketiga, orientasi. dari perbedaan pertama dan kedua dapat pula diambil kesimpulan bahwa teori konvergensi dan teori fitrah memiliki orientasi yang berbeda. Teori konvergensi cenderung antroposentris berorientasi pada kehidupan dunia semata. Sedangkan teori fitrah memiliki orientasi ganda yakni dunia dan akhirat.

Keterbatasan dari kajian ini adalah menyoroti hubungan sebab akibat antara dua teori barat dan teori islam. Saran untuk peneliti yang membuat kajian serupa mungkin untuk menambah pemahaman tentang topik penelitian dari sudut pandang lain untuk memperluas wacana cakrawala keilmuan yang multidisipliner.

\section{Daftar Pustaka}

Abu Ahmadi, \& Uhbiyati, N. (2015). Ilmu Pendidikan. Jakarta: Rineka Cipta.

Akademik, D. (2008). Buku panduan pengembangan kurikulum berbasis kompetensi pendidikan tinggi. Jakarta: Direktorat Jenderal Pendidikan Tinggi RI.

An-Nahlawi, A. (1403). Ushulut Tarbiyah Islamiyah wa Asalibiha fil Baiti wal Madrasati wal Mujtama'. Beirut: Dar al-Fikr Al-Mu'asyir.

Az-Zarnuji, S. (1978). Ta'lim al-Muta'lim Ter. Aliy As'ad. Kudus: Menara Kudus.

Bakhri, S. (2016). Teori Fitrah Anak dalam Islam dan Relevansinya dengan Teori Konvergensi dalam Aliran Pendidikan (doctoral). Universitas Islam Negeri Alauddin Makassar. Retrieved from http://repositori.uinalauddin.ac.id/299/

Basri, H., \& Saebani, B. A. (2010). ILMU PENDIDIKAN ISLAM. Bandung: Pustaka Setia.

Fauziyah, S. (2017). Konsep Fitrah dan Bedanya Dari Nativisme, Empirisme, dan Konvergensi. Aqlania, 8(01), 83-102. 


\section{WACANA}

Hamdu, G., \& Agustina, L. (2011). Pengaruh motivasi belajar siswa terhadap prestasi belajar IPA di sekolah dasar. Jurnal Penelitian Pendidikan, 12(1), 90-96.

Kiswoyowati, A. (2011). Pengaruh motivasi belajar dan kegiatan belajar siswa terhadap kecakapan hidup siswa. Portal Jurnal Universitas Pendidikan Indonesia, 2(1), 12-16.

Lia, T. A. (2012). Pengaruh Penggunaan Alat Peraga Kit Ipa Terhadap Hasil Belajar Siswa Mata Pelajaran Ipa Kelas V Sdn Ambulu 01-Jember Tahun Pelajaran 2011/2012.

Napis, A. D. (2017). PERAN KELUARGA DALAM PENDIDIKAN. Jurnal Buah Hati, 4(2). Nata, A. (2012). Ilmu Pendidikan Islam. Jakarta: Kencana.

purwanto, N. (2013). Psikologi Penddidikan (Cet. 26). Bandung: Remaja Rosdakarya. Raharjo, D. (1996). Ensiklopedi al-Qur'an Tafsir Sposial Berdasarkan Konsep-Konsep Kunci. Jakarta: Paramadina.

Ristiyani, E., \& Bahriah, E. S. (2016). Analisis kesulitan belajar kimia siswa di SMAN X Kota Tangerang Selatan. Jurnal Penelitian Dan Pembelajaran IPA, 2(1), 1829.

Saragih, A. H. (2008). Kompetensi minimal seorang guru dalam mengajar. Jurnal Tabularasa, 5(1), 23-34.

Sukardjo, M., \& Qomarudin, U. (2012). Landasan Pendidikan Konsep dan Aplikasinya. Jakarta: Raja Grafindo Persada.

Suryabrata, S. (2014). Psikologi Pendidikan. Jakarta: Rajawali Pers.

Syah, M. (2014). psikologi Pendidikan. Bandung: Remaja Rosdakarya.

TAP MPR No.IV 1978 - Google Scholar. (n.d.). Retrieved November 18, 2018, from https://scholar.google.co.id/scholar?hl=en\&as_sdt=0\%2C5\&q=TAP+MPR+N o.IV+1978\&btnG=

Undang-Undang, R. I. (1989). No. 2 Tahun 1989. Sistem Pendidikan Nasional. Undang-undang RI No.20 tahun 2003 tentang sistem pendidikan Nasional. (n.d.) (cet. I). Bandung: Fokusmedia.

Wahyuddin, W. (2017). PENDIDIKAN SEPANJANG HAYAT MENURUT PERSPEKTIF ISLAM. SAINTIFIKA ISLAMICA: Jurnal Kajian Keislaman, 3(02), 191-208. 